\title{
Respon Mahasiswa terhadap Metode Meresume di Youtube sebagai Metode Pembelajaran Daring Matematika
}

\author{
Rospala Hanisah Yukti Sari ${ }^{1}$ \\ ${ }^{1}$ Prodi Pendidikan Guru Sekolah Dasar, Fakultas Ilmu Keguruan dan Pendidikan, Universitas Muhammadiyah Palangkaraya \\ Jl. RTA Milono, KM 1,5, Kecamatan Pahandut, Palangkaraya, Indonesia \\ rospalahanisah@gmail.com
}

\begin{abstract}
The majority of social media users accessing the Youtube platform cannot be separated from the advantages in it. The main advantage is the ease of accessing and uploading videos available on Youtube with the internet for free without any limitations of space and time. The purpose of this study was to determine and describe student responses when using the resume method via Youtube social media in learning mathematics. The method used in this research is descriptive qualitative method by collecting questionnaires to students who take mathematics courses. The results of the average percentage score of the overall student response to resume videos on Youtube reached $80 \%$. The data analysis used in this research is descriptive quantitative, while to test the validity of the questionnaire with Pearson correlation and the reliability of the questionnaire with Cronbach Alpha using SPSS. This shows that the student's response when submitting a video resume on Youtube in learning mathmatics is positive.
\end{abstract}

Keywords: Student College Response, Summarizing, Youtube, Math

\begin{abstract}
Abstrak
Mayoritas pengguna media sosial mengakses platform Youtube tidak lepas dari kelebihan di dalamnya. Kelebihan yang utama yaitu kemudahan dalam mengakses dan mengunggah video yang tersedia di Youtube dengan internet secara gratis tanpa ada batasan ruang dan waktu. Tujuan dari penelitian ini adalah untuk mengetahui dan mendeskripsikan respon mahasiswa ketika menggunakan metode meresume via media sosial Youtube dalam pembelajaran matematika. Metode yang digunakan dalam penelitian ini adalah metode kualitatif deskriptif dengan mengumpulkan angket kepada mahasiswa yang mengambil mata kuliah matematika. Hasil rata-rata persentase skor keseluruhan respon mahasiswa terhadap meresume video di Youtube mencapai $80 \%$. Analisis data yang digunakan dalam penelitian ini adalah kuantitatif deskriptif sedangkan untuk menguji validitas angket dengan Pearson Correlation dan reliabilitas angket dengan Cronbach Alpha menggunakan SPSS. Hal ini menunjukkan bahwa respon mahasiswa ketika metika meresume video di Youtube pada pembelajaran matematika adalah positif.
\end{abstract}

Kata kunci: Respon Mahasiswa, Meresume, Youtube, Matematika

Copyright (c) 2022 Rospala Hanisah Yukti Sari

$\triangle$ Corresponding author: Rospala Hanisah Yukti Sari

Email Address: rospalahanisah@gmail.com

Received 06 January 2022, Accepted 26 January 2022, Published 04 February 2022

\section{PENDAHULUAN}

Dinamika perkembangan teknologi semakin pesat dan canggih berkorelasi terhadap pengguna internet yang semakin meningkat. Menteri Komunikasi dan Informasi mengumumkan bahwa jumlah pengguna internet di Indonesia Tahun 2021 naik 11 persen dari tahun sebelumnya menjadi 202,6 juta pengguna dari populasi RI sebanyak 266,9 juta menurut data Badan Pusat Statistik (Kemenkominfo, 2021). Kondisi penggunaan internet yang meningkat ini salah satunya dipengaruhi juga dengan kebijakan social distancing yang diterapkan oleh pemerintah sejak awal Tahun 2020 dimana pandemi covid-19 mulai muncul. Dengan kebijakan social distancing, kegiatan pembelajaran pun mengalami trasnformasi dari pembelajaran luring ke pembelajaran daring. Kondisi ini juga akan berimbas terhadap suasana belajar dan mental mahasiswa khususnya pada mata kuliah matematika. 
Matematika merupakan ilmu pasti yang terdiri dari rumus-rumus dengan gagasan dan aksioma serta bilangan-bilangan di dalamnya yang digunakan dalam upaya memecahkan masalah (Molina, 2014). Matematika digunakan dalam upaya memecahkan masalah dalam kehidupan sehari-hari dengan cara melakukan simulasi simbolik. Upaya manipulasi bilangan dan lambang dalam matematika dapat dilakukan dengan cara menghitung, dan mengukur sistematika pembelajaran untuk mendapatkan masalah. Pendapat ini senada dengan Ziegler bahwa matematika adalah pengetahuan yang dikelola berdasarkan kegiatan mengukur, menghitung, berhitung dan sistematika pembelajaran dengan mengabstraksikan suatu masalah dalam mendapatkan pemecahan masalah dengan menggunakan logika yang sistematis (Ziegler \& Loos, 2010). Selain itu, dalam mengembangkan kemampuan dalam matematika seperti analitis, logis, kritis, sistematis dan kreatif, ketika mahasiswa belajar matematika, mahasiswa juga dilatih untuk dapat memecahkan berbagai masalah matematika dengan melibatkan aktivitas mental. Aktivitas mental merupakan perasaan, emosi dan sensasi (Whitehead, 2012). Dalam melaksanakan aktivitas mental ketika belajar matematika, maka aktivitas mental tersebut akan menghasilkan konstruksi pemahaman dari suatu pengetahuan atau ide matematika yang dapat dilakukan dengan memiliki dan memahami cara berpikir matematis. Proses kontruksi pemahaman matematika diperlukan suatu proses yang kontinu serta menggunakan strategi pembelajaran yang sesuai agar tujuan pembelajaran dapat tercapai terutama pembelajaran matematika dengan daring. Pembelajaran matematika dengan daring membutuhkan upaya yang maksimal bagi para pendidik agar konsep matematika dapat dipahami dengan baik oleh mahasiswa. Salah satu cara yang dilakukan oleh dosen agar pembelajaran matematika dapat menarik mahasiswa yaitu dengan menggunakan media Youtube.

Youtube adalah situs web berbagi video yang ditemukan dan dikembangkan oleh Chad Hurley, Steve Chen, dan Jawed Karim pada Tahun 2005 dan terus berkembang hingga saat ini. Bahkan Youtube menduduki posisi pertama sebagai media sosial yang paling diminati di masa pandemic Covid-19. Berdasarkan Survei Jakpat (Jakarta Plaform), YouTube merupakan media sosial yang paling banyak diakses masyarakat Indonesia pada semester I-2021. Pasalnya, ada 82\% responden yang menggunakan platform Youtube.Sebagian besar atau 65\% responden mengakses YouTube karena platform tersebut dinilai menghibur. Sebanyak 56\% responden juga mengakses YouTube karena menganggapnya informatif. Data dikumpulkan pada Januari-Juni 2021 secara daring di aplikasi Jakpat dengan tingkat margin of error di bawah 3\% (Katadata, 2021). 


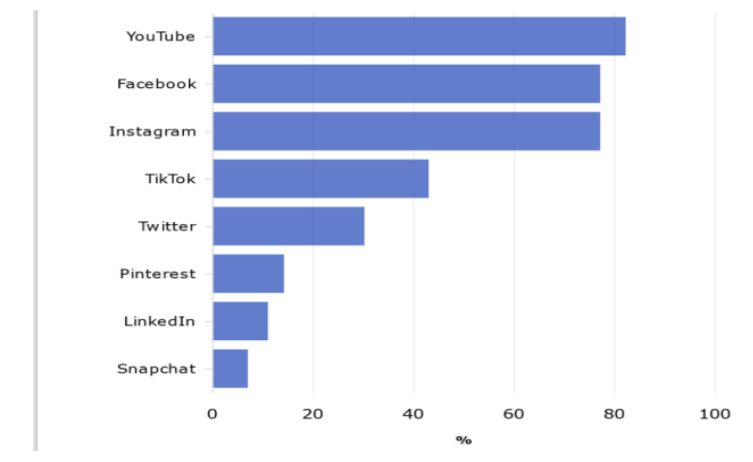

Gambar 1. Grafik Pengguna Sosial Media Kuartal 1 Tahun 2021

Mayoritas pengguna media sosial mengakses platform Youtube tidak lepas dari kelebihan di dalamnya. Kelebihan yang utama yaitu kemudahan dalam mengakses dan mengunggah video yang tersedia di Youtube dengan internet secara gratis tanpa ada batasan ruang dan waktu. Kelebihan yang lainnya yaitu video dengan mudah dapat dibagikan serta dapat diakses melalui perangkat mobile seperti smartphone (Srinivasacharlu, 2020). Hal ini dapat memberikan kebebasan bagi pengguna dalam mengunggah dan mengakses konten video yang mereka miliki tanpa harus mengkhawatirkan pembatasan waktu dan alat yang harus digunakan. Selain itu, dengan semakin banyaknya pengguna smartphone saat ini, maka semakin memperbesar peluang konten video yang diunggah akan dilihat oleh pengguna lainnya.

Dengan adanya potensi Youtube sebagai platform yang paling diminati masyarakat serta kemudahan dalam mengakses platform tersebut., maka Youtube menjadi salah satu sosial media yang dimanfaatkan oleh guru dan dosen dalam membantu menyampaikan konsep matematika. Hasil penelitian yang dilakukan oleh Humaidi et al. (2022) mengungkapkan bahwa respon siswa terhadap penggunaan media sosial video Youtube pada pembelajaran matematika adalah sangat positif. Namun perlu adanya upaya perhatian khusus terkait dengan penyajian tampilan video dan struktur penyampaian materi sehingga siswa lebih tertarik dan percaya diri setelah menggunakan media. Dengan melihat adanya kelebihan dalam menggunakan fitur Youtube, penulis optimis bahwa ada potensi yang baik jika Youtube digunakan dalam pembelajaran matematika. Hasil penelitian dari Setiyana \& Kusuma (2021) mengungkapkan bahwa potensi pemanfaatan YouTube dalam pembelajaran matematika memiliki dampak positif dalam pembelajaran sehingga dapat bermanfaat karena dapat menambah minat serta dapat memotivasi siswa untuk belajar .

Adapun judul yang dirumuskan dalam penelitian ini adalah "Respon Mahasiswa tentang Resume Materi di Youtube sebagai Metode Pembelajaran Daring Matematika". Metode yang digunakan dalam penelitian ini adalah metode kualitatif deskriptif dengan mengumpulkan angket kepada mahasiswa yang mengambil mata kuliah matematika. Analisis data yang digunakan dalam penelitian ini adalah kuantitatif deskriptif. Teknik pengumpulan data yang digunakan dalam penelitian ini adalah angket yang dibuat dalam Google Form. Tujuan dari penelitian ini adalah untuk mengetahui 
dan mendeskripsikan respon mahasiswa ketika menggunakan metode meresume via media sosial Youtube dalam pembelajaran matematika.

\section{METODE}

Penelitian ini merupakan penelitian kuantitatif deskriptif dimana tujuan utamanya adalah untuk mengetahui respon mahasiswa terhadap meresume dengan video Youtube dengan cara analisis terhadap angka, mulai dari pengumpulan data, penafsiran sistematis, terencana, dan terstruktur terhadap data tersebut, serta penampilan dari hasilnya, demikian pula pada tahap kesimpulan penelitian akan lebih baik bila disertai dengan gambar, tabel, grafik, atau tampilan lainnya (Siyoto \& Sodik, 2015: 17). Teknik pengumpulan data yang digunakan dalam penelitian ini adalah angket yang dibuat dalam Google Form. Pembelajaran melalui Youtube sendiri digunakan di FKIP PGSD Universitas Muhammadiyah Palangkaraya sebagai media pembelajaran daring pada mata pelajaran matematika sejak awal Semester Ganjil Tahun Ajaran 2021/2022, yaitu bulan September 2021.

Penelitian dilaksanakan pada awal Semester Genap 2021/2022 sebagai bentuk refleksi pelaksaan pembelajaran daring pada semester sebelumnya. Waktu pelaksanaan penelitian yaitu pada bulan September 2021. Metode pengambilan sampel yaitu berdasarkan sampel bertujuan dimana sampel yang diambil hanya mahasiswa/i Semester 1 di FKIP PGSD Universitas Muhammadiyah Palangkaraya yang mengambil mata kuliah matematika. Sampel penelitian adalah Mahasiswa/i Semester 1 di FKIP PGSD Universitas Muhammadiyah Palangkaraya sebanyak 82 orang.

Adapun uji validitas angket yang digunakan adalah Pearson Correlation dan reliabilitas angket yang digunakan adalah Cronbach's Alpha. Uji validitas angket dan reliabilitas instrument dianalisis menggunakan SPSS. Validitas dan reliabilitas instrumen akan diuji dengan sampel 82 orang. Untuk masing-masing pernyataan, skor akan dinilai menggunakan skala Likert, yaitu: Sangat Setuju (skor 5), Setuju (skor 4), Netral (skor 3), Tidak Setuju (skor 2), dan Sangat Tidak Setuju (skor 1). Selanjutnya, angket respon tersebut disusun dalam format Google Form hingga kemudian dibagikan kepada siswa yang sebelumnya telah menggunakan media video Youtube dalam kegiatan pembelajaran matematika. Untuk rumus presentase hasil dapat dihitung berdasarkan rumus sebagai berikut.

$$
P S=\frac{\mathrm{S}}{\mathrm{T}} \times 100 \%
$$

Keterangan:

PS : Persentase Skor

S : Skor yang diperoleh

$\mathrm{T} \quad$ : Total Skor (maksimum)

Berdasarkan persentase skor yang diperoleh untuk setiap indikator, dapat dilihat kategori respon siswa terhadap indikator yang bersangkutan dengan kategori pada Tabel 2 (Riduwan, 2007). Respon siswa terhadap media video Youtube sebagai media pembelajaran pembelajaran pada 
pembelajaran matematika ditentukan berdasarkan rata-rata persentase skor dari setiap indikator yang ada, untuk kemudian disesuaikan dengan kategori respon berdasarkan Tabel 1.

Tabel 1. Kategori Respon Siswa

\begin{tabular}{|c|c|}
\hline Persentase Skor & Kategori Respon \\
\hline $81 \%-100 \%$ & Sangat Positif \\
\hline $61 \%-80 \%$ & Positif \\
\hline $41 \%-60 \%$ & Cukup \\
\hline $21 \%-40 \%$ & Negatif \\
\hline $0 \%-20 \%$ & Sangat Negatif \\
\hline
\end{tabular}

Sumber: Arikunto (2009: 35)

Untuk memperoleh data tentang respon siswa, digunakan angket respon penggunaan media yang digunakan pada penelitian Lijana, dkk. pada Tahun 2020. Angket respon siswa terdiri dari dua aspek, yaitu tanggapan dan reaksi (Lijana et al., 2020). Kisi-kisi angket dapat dilihat pada Tabel 2.

Tabel 2. Kisi-kisi Angket Respon Siswa terhadap Media Video Youtube

\begin{tabular}{|c|c|c|c|}
\hline Aspek & Indikator & Keterangan & Pernyataan \\
\hline \multirow[t]{5}{*}{ Tanggapan } & \multirow[t]{2}{*}{ Format } & \multirow{2}{*}{$\begin{array}{l}\text { Kejelasan suara, } \\
\text { gambar, } \\
\text { dan bahasa yang } \\
\text { digunakan }\end{array}$} & - Konten yang disampaikan dengan jelas. \\
\hline & & & $\begin{array}{l}\text { - Bahasa yang digunakan dalam video } \\
\text { youtube dapat dimengerti dengan baik. }\end{array}$ \\
\hline & \multirow[t]{3}{*}{ Relevansi } & \multirow{3}{*}{$\begin{array}{l}\text { Kebermanfaatan dan } \\
\text { kecocokan dengan } \\
\text { kebutuhan siswa. }\end{array}$} & $\begin{array}{l}\text { - Konten yang disampaikan sesuai dengan } \\
\text { materi yang diajarkan. }\end{array}$ \\
\hline & & & $\begin{array}{l}\text { - Konten yang disampaikan memberikan } \\
\text { manfaat dalam pembelajaran yang } \\
\text { dilakukan } \\
\text { - Media (video Youtube) yang dipakai } \\
\text { sesuai dengan kondisi pembelajaran saat } \\
\text { ini. }\end{array}$ \\
\hline & & & $\begin{array}{l}\text { - Kegiatan meresume dengan } \\
\text { menggunakan video youtube sebagai } \\
\text { media pembelajaran matematika dapat } \\
\text { meningkatkan pemahaman anda dalam } \\
\text { memahami materi matematika. } \\
\text { - Menggunakan video youtube merupakan } \\
\text { langkah yang tepat dalam pembelajaran } \\
\text { matematika. }\end{array}$ \\
\hline \multirow[t]{3}{*}{ Reaksi } & \multirow[t]{2}{*}{ Kepuasan } & \multirow[t]{2}{*}{$\begin{array}{l}\text { Perasaan positif } \\
\text { terhadap pengalaman } \\
\text { belajar yang dilakukan. }\end{array}$} & $\begin{array}{l}\text { - Media (video Youtube) yang dipakai } \\
\text { sesuai dengan keinginan dan kebutuhan } \\
\text { saya. }\end{array}$ \\
\hline & & & $\begin{array}{l}\text { - Penggunaan media (video youtube) } \\
\text { memberikan pengalaman belajar } \\
\text { matematika yang positif. } \\
\text { - Belajar matematika via youtube } \\
\text { menyenangkan. }\end{array}$ \\
\hline & Percaya Diri & Harapan positif setelah & - Melalui \\
\hline
\end{tabular}




\begin{tabular}{|l|l|l|}
\hline \multirow{2}{*}{} & menggunakan media. & $\begin{array}{l}\text { memiliki dalam } \\
\text { menyelesaikan tugas saya. }\end{array}$ \\
\cline { 3 - 3 } & & $\begin{array}{l}\text { - Setelah melihat video di Youtube, saya } \\
\text { yakin dapat menyelesaikan tugas dengan } \\
\text { baik. }\end{array}$ \\
\hline
\end{tabular}

\section{HASIL DAN DISKUSI}

Data penelitian dianalisis dengan menggunakan bantuan software SPSS. Sebelum melakukan analisis terhadap tingkat stress mahasiswa, terlebih dahulu melakukan uji validitas dan reliabilitas pada angket tingkat stress mahasiswa UM Palangkaraya dengan hasil sebagai berikut.

Tabel 3. Uji Validitas

\begin{tabular}{|c|c|c|c|c|c|c|c|c|c|c|c|c|}
\hline Number & $\mathbf{1}$ & $\mathbf{2}$ & $\mathbf{3}$ & $\mathbf{4}$ & $\mathbf{5}$ & $\mathbf{6}$ & $\mathbf{7}$ & $\mathbf{8}$ & $\mathbf{9}$ & $\mathbf{1 0}$ & $\mathbf{1 1}$ & $\mathbf{1 2}$ \\
\hline $\begin{array}{c}\text { Pearson } \\
\text { Correlation }\end{array}$ & 0,827 & 0,800 & 0,804 & 0,841 & 0,841 & 0,812 & 0,718 & 0,809 & 0,820 & 0,842 & 0,838 & 0,832 \\
\hline Conclusion & Valid & Valid & Valid & Valid & Valid & Valid & Valid & Valid & Valid & Valid & Valid & Valid \\
\hline
\end{tabular}

Suatu variabel dapat dikatakan valid apabila nilai $r$ hitung $>0,05$. Berdasarkan nilai alpha 0,05 , sedangkan nilai Pearson Correlation minimal adalah 0,7182 sebanyak 82 responden $(\mathrm{N})$ dengan 12 item kuesioner, maka semua nilai Pearson Correlations tiap item di atas 0.718. Maka dapat disimpulkan bahwa 12 item kuesioner ini sudah valid.

Tabel 4. Uji Reliabilitas

\begin{tabular}{|c|r|}
\hline \multicolumn{2}{|c|}{ Reliability Statistics } \\
\hline Cronbach's Alpha & N of Items \\
\hline, 778 & 15 \\
\hline
\end{tabular}

Suatu variabel dapat dikatakan reliabel apabila nilai Cronbach's Alpha $>0,60$. Berdasarkan Uji Reliabilitas, nilai Cronbach's Alpha adalah 0,778 dengan menggunakan 82 responden (N) dengan batas apha 0.05 , maka dapat disimpulkan bahwa angket kuisioner tersebut sudah reliabel. Untuk analisis reliabel tiap butir angket, dapat dijabarkan sebagai berikut:

Tabel 5. Uji Reliabilitas Setiap Butir Kuisioner

\begin{tabular}{|c|c|c|c|c|c|c|c|c|c|c|c|c|}
\hline Number & $\mathbf{1}$ & $\mathbf{2}$ & $\mathbf{3}$ & $\mathbf{4}$ & $\mathbf{5}$ & $\mathbf{6}$ & $\mathbf{7}$ & $\mathbf{8}$ & $\mathbf{9}$ & $\mathbf{1 0}$ & $\mathbf{1 1}$ & $\mathbf{1 2}$ \\
\hline $\begin{array}{c}\text { Cronbabch's } \\
\text { Alpha if Item } \\
\text { Deleted }\end{array}$ & 0,759 & 0,762 & 0,760 & 0,757 & 0,756 & 0,756 & 0,764 & 0,761 & 0,760 & 0,761 & 0,762 & 0,760 \\
\hline Conclusion & Valid & Valid & Valid & Valid & Valid & Valid & Valid & Valid & Valid & Valid & Valid & Valid \\
\hline
\end{tabular}

Berdasarkan Tabel 5 memberikan gambaran tentang nilai statistik untuk ke-12 item pertanyaan angket. Pada kolom “Cronbabch's Alpha if Item Deleted" dapat diketahui nilai Cronbach's Alpha 
untuk 12 item soal adalah > 0,60, maka dapat disimpulkan bahwa ke-12 item pertanyaan angket reliabel. Adapun statistik deskriptif dari variabel respon siswa sebagai berikut:

Tabel 6. Statistik Deskriptif Variabel Respon Mahasiswa

\begin{tabular}{|c|r|r|r|r|}
\hline & \multicolumn{4}{|c|}{ Scale Statistics } \\
\hline Variabel & Mean & Variance & N of Items & N of Responden \\
\hline Respon Mahasiswa & 0,625 & 0,005 & 12 & 82 \\
\hline
\end{tabular}

Berdasarkan Tabel 6, dapat diketahui bahwa nilai rata-rata variabel respon mahasiswa diperoleh nilai sebesar 0,625, dan memiliki varians 0,05. Meresume dengan media video Youtube bertujuan agar siswa dapat mempelajari dan memahami matematika secara mandiri. Youtube dipilih karena mahasiswa sudah familiar dan berbagai kemudahan dalam mengakses video di dalamnya. Untuk mengetahui respon mahasiswa ketika menerapkan metode meresume media Youtube dalam pembelajaran matematika, digunakan angket yang disebar melalui Google Form. Dari 82 Mahasiswa yang mengisi angket diperoleh data yang ditampilkan Tabel 3 .

Tabel 7. Jumlah Responden Angket Setiap Indikator

\begin{tabular}{|c|c|c|c|c|c|c|c|}
\hline Indikator & No & Pernyataan & 5 & 4 & 3 & 2 & 1 \\
\hline \multirow[t]{2}{*}{ Format } & 1 & $\begin{array}{l}\text { Bahasa yang digunakan dalam video youtube } \\
\text { dapat dimengerti dengan baik. }\end{array}$ & 15 & 40 & 13 & 0 & 0 \\
\hline & 2 & Konten yang disampaikan dengan jelas. & 15 & 42 & 11 & 0 & 0 \\
\hline \multirow{5}{*}{ Relevansi } & 3 & $\begin{array}{l}\text { Media (video Youtube) yang dipakai sesuai } \\
\text { dengan kondisi pembelajaran saat ini. }\end{array}$ & 11 & 41 & 16 & 0 & 0 \\
\hline & 4 & $\begin{array}{l}\text { Kegiatan meresume dengan menggunakan } \\
\text { video youtube sebagai media pembelajaran } \\
\text { matematika dapat meningkatkan pemahaman } \\
\text { anda dalam memahami materi matematika. }\end{array}$ & 14 & 32 & 21 & 1 & 0 \\
\hline & 5 & $\begin{array}{l}\text { Menggunakan video youtube merupakan } \\
\text { langkah yang tepat dalam pembelajaran } \\
\text { matematika. }\end{array}$ & 12 & 28 & 27 & 1 & 0 \\
\hline & 6 & $\begin{array}{l}\text { Konten yang disampaikan sesuai dengan } \\
\text { materi yang diajarkan. }\end{array}$ & 15 & 40 & 13 & 0 & 0 \\
\hline & 7 & $\begin{array}{l}\text { Konten yang disampaikan memberikan } \\
\text { manfaat dalam pembelajaran yang dilakukan. }\end{array}$ & 17 & 43 & 8 & 0 & 0 \\
\hline \multirow{3}{*}{ Kepuasan } & 11 & $\begin{array}{l}\text { Belajar matematika via youtube } \\
\text { menyenangkan. }\end{array}$ & 12 & 34 & 22 & 0 & 0 \\
\hline & 12 & $\begin{array}{l}\text { Media (video Youtube) yang dipakai sesuai } \\
\text { dengan keinginan dan kebutuhan Anda. }\end{array}$ & 12 & 36 & 20 & 0 & 0 \\
\hline & 13 & $\begin{array}{l}\text { Meresume dengan menggunakan video } \\
\text { youtube sebagai media pembelajaran } \\
\text { matematika dapat meningkatkan minat anda } \\
\text { dalam belajar matematika }\end{array}$ & 15 & 40 & 13 & 0 & 0 \\
\hline $\begin{array}{l}\text { Percaya } \\
\text { Diri }\end{array}$ & 14 & $\begin{array}{l}\text { Melalui video di Youtube, saya memiliki } \\
\text { gambaran dalam menyelesaikan tugas saya }\end{array}$ & 13 & 39 & 16 & 0 & 0 \\
\hline \multicolumn{3}{|r|}{ Total } & 151 & 415 & 180 & 2 & $\mathbf{0}$ \\
\hline & & Persentase $(\%)$ & 20,19 & 55,48 & 24,06 & 0,27 & $\mathbf{0}$ \\
\hline
\end{tabular}

Keterangan:

$5=$ Sangat Positif $\quad 2=$ Negatif

$4=$ Positif $\quad 1=$ Sangat Negatif

$3=$ Netral 
Dari Tabel 3, diketahui bahwa mayoritas mahasiswa memberikan respon positif sebanyak 55,48\% ketika menerapkan metode meresume di Youtube dalam pembelajaran matematika. Mayoritas mahasiswa yang merespon positif menyatakan bahwa dengan menonton video pembelajaran di YouTube tidak hanya penjelasan yang dapat di mengerti tetap juga ada gambar + video yang di tampilkan sehingga menarik perhatian untuk lebih fokus dalam memahami materi. Adapun respon yang kedua, yaitu memberikan respon netral yaitu sebesar 24,06\%. Mahasiswa yang merespon netral mengatakan bahwa mereka senang meresume via youtube karena jika via youtube bisa mengulang kembali bagian-bagian yang belum dipahami, agar dapat memahami materi mana saja yang masih belum dikuasai. Di youtube juga kita bisa menemukan berbagai video pembelajaran, baik dimulai dari jenjang yang rendah sampai jenjang yang lebih tinggi. Akan tetapi via YouTube juga mempunyai kendala misalnya jika agak sulit memahami materi tersebut atau kata-kata yang disampaikan membuat bingung, maka tidak bisa menyanggah hal tersebut dan juga via youtube, jika jaringan tidak stabil maka akan menggangu prosesnya pembelajaran. Sedangkan, sebanyak 20,19\% memberikan respon sangat positif ketika menerapkan metode meresume di Youtube dalam pembelajaran matematika. Mahasiswa yang merespon sangat positif mengemukakan bahwa belajar via youtube penjelasannya sangat cepat dan mudah dipahami. Untuk lebih jelasnya persentase respon mahasiswa ketika menerapkan metode meresume di Youtube dalam pembelajaran matematika dapat dilihat dalam Gambar 1.

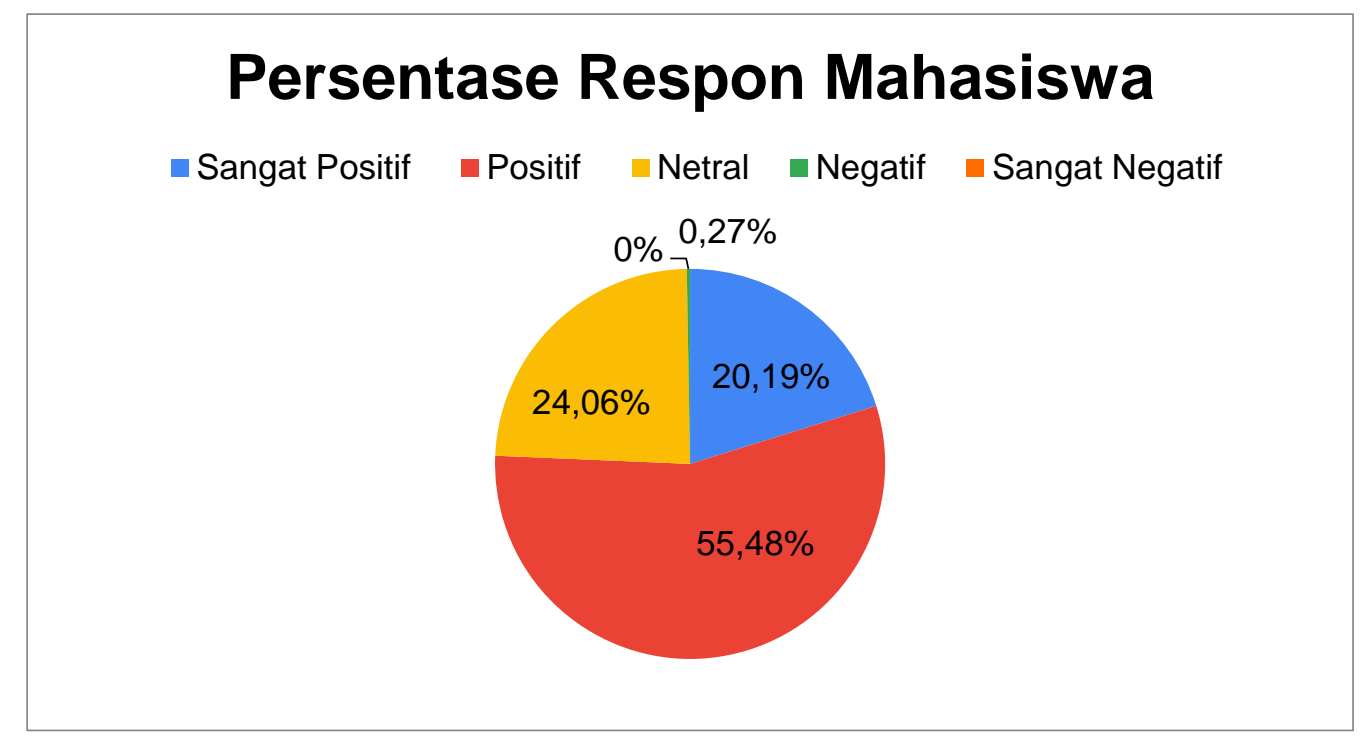

Gambar 1. Persentase Respon Mahasiswa ketika Menggunakan Metode Meresume di Youtube

Setelah merumuskan persentase dari respon mahasiswa yang tertera pada Gambar 1 ketika menggunakan metode meresume di Youtube, maka akan dilakukan proses rincian tentang respon mahasiswa untuk setiap indikator yang dapat dilihat dalam Tabel 4. 
Tabel 8. Rincian Respon Mahasiswa untuk Setiap Indikator

\begin{tabular}{|c|l|c|c|}
\hline \multirow{2}{*}{ Aspek } & \multicolumn{1}{|c|}{ Indikator } & \multicolumn{2}{c|}{ Respon Siswa } \\
\cline { 2 - 4 } & & Persentase Skor (\%) & Kategori Respon \\
\hline \multirow{3}{*}{ Tanggapan } & Format & $81 \%$ & Sangat Positif \\
\cline { 2 - 4 } & Relevansi & $78 \%$ & Positif \\
\cline { 2 - 4 } & Rata-Rata Indikator Tanggapan & $\mathbf{8 0 \%}$ & Positif \\
\hline \multirow{3}{*}{ Reaksi } & Kepuasan & $79 \%$ & Positif \\
\cline { 2 - 4 } & Percaya Diri & $79 \%$ & Positif \\
\cline { 2 - 4 } & Rata-Rata Indikator Reaksi & $\mathbf{7 9 \%}$ & Positif \\
\hline \multicolumn{2}{|c|}{ Total } & $\mathbf{8 0 \%}$ & Positif \\
\hline
\end{tabular}

Berdasarkan Tabel 4, diketahui bahwa indikator Format memperoleh persentase skor tertinggi yaitu $81 \%$ (sangat positif). Hal tersebut menunjukkan bahwa video Youtube merupakan alternative solusi yang dapat digunakan untuk mengatasi permasalahan yang terdapat dalam pembelajaran daring (Daniati, 2020; Sadikin \& Hamidah, 2020; Tarida \& Indriyani, 2020). Dengan keunggulan yang dimiliki oleh Youtube sehingga dapat diakses oleh siswa. Selain itu, setiap materi dalam Youtube berisi penjelasan-penjelasan yang mudah dipahami (Pambudi et al., 2019). Penjelasan materi di Youtube, mencakup dalam bahasa yang digunakan dalam video youtube dapat dipahami dengan baik serta konten yang disampaikan dengan jelas sehingga dapat meningkatan pemahaman mahasiswa dalam perkuliahan matematika. Penjelasan materi di Youtube dapat berupa video tutorial. Video tutorial merupakan rangkaian dari gambar hidup yang berisi pesan - pesan, dan bahan pengajaran yang bertujuan untuk memberikan pemahaman dalam pembelajaran oleh seorang pengajar atau biasa dikenal dengan istilah tutor (Wirasasmita \& Putra, 2018). Kejelasan suara dan gambar akan mendukung pembelajaran mahasiswa dalam mengamati konten video sehingga penjelasan yang disampaikan dapat dipahami dengan baik (Tutiasri \& Laminto, 2020). Dengan demikian, kombinasi yang baik dari ketiga hal (suara, gambar dan bahasa) diharapkan dapat membantu mahasiswa dalam mengikuti pembelajaran sehingga mendapatkan hasil belajar yang optimal.

Berbanding terbalik dengan indikator Format, pada indikator Relevansi memperoleh persentase skor $78 \%$ (Positif) merupakan indicator yang memiliki skor paling sedikit. Indikator relevansi berkaitan penggunaan video Youtube merupakan langkah yang tepat dalam pembelajaran karena mempertimbangkan manfaat yang diberikan ketika menggunakan Youtube sebagai sarana pendidikan. Youtube sebagai alat pendidikan melahirkan perhatian yang besar untuk menciptakan praktek-praktek pendidikan terbaik (Suwarno, 2017). Manfaat terhadap proses pembelajaran matematika yaitu berkembangnya imaginasi dan kreatifitas siswa (Lestari \& Bahrozi, 2021) dan mudah diakses setiap saat (Sari, 2020). Melalui video Youtube siswa dapat mempelajari materi secara fleksibel dari segi waktu dan tempat secara mandiri (Chandra \& Nugroho, 2017; Lasabuda, 2017; Tutiasri \& Laminto, 2020). Keuntungan lain dari video Youtube yaitu dapat memutar ulang bagian-bagian yang belum dipahami sehingga dapat membantu pemahaman mahasiswa terhadap materi yang diberikan (Srinivasacharlu, 2020; Sutartu \& Astuti, 2021). Hal ini sesuai dengan karakteristik pembelajaran 
matematika dimana mayoritas menggunakan kegiatan prosedural penyelesaian masalah matematika, sehingga mahasiswa diharapkan dapat memahami setiap langkah dan urutan dalam penyelesaian masalah

Pada Tabel 4 ditunjukkan bahwa persentase indikator kepuasan mencapai 79\% dan berada pada kategori positif. Hal ini menunjukkan bahwa sebagian besar mahasiswa merasa sangat puas ketika meresume video di Youtube. Kepuasan siswa ini mencerminkan meningkatnya minat mahasiswa ketika belajar via youtube. Hal ini sesuai dengan Mujianto (2019) yang mengemukakan bahwa pemanfaatan media Youtube sebagai media ajar dapat berperan positif secara signifikan terhadap peningkatan minat belajar mahasiswa.

Selain pada indikator kepuasan, indikator percaya diri juga memperoleh persentase skor $79 \%$. Meskipun berada dalam kategori positif, hal ini menunjukkan bahwa indikator ini perlu mendapat perhatian lebih. Indikator ini terkait dengan kemampuan video dalam memberikan gambaran dalam menyelesaikan tugas, serta keyakinan siswa dalam menyelesaikan tugas setelah mencermati video pada Youtube. Pada pengembangan video berikutnya, teknik dan struktur penyampaian materi pada video.

Pada indikator format memperoleh persentase $83 \%$ (sangat positif). Indikator format berkaitan dengan penggunaan bahasa serta kejelasan suara dan gambar pada video pembelajaran. Dalam hal ini, berarti bahasa yang digunakan dapat dimengerti dengan baik oleh siswa. Penggunaan bahasa yang komunikatif dan sesuai dengan tingkat perkembangan siswa penting agar pesan dan isi dari video dapat ditangkap dengan jelas oleh siswa. Dengan menggunakan bahasa yang baik diharapkan dapat membantu siswa dalam memahami materi yang dipelajari. Sedangkan kejelasan suara dan gambar akan mendukung siswa dalam mengamati konten video sehingga penjelasan yang disampaikan dapat dipahami dengan baik (Tutiasri \& Laminto, 2020). Kombinasi dari ketiga hal ini (bahasa, suara, dan gambar) diharapkan akan membantu siswa dalam mengikuti pembelajaran sehingga lebih jauh akan memberikan hasil belajar yang optimal.

Pada Tabel 3 ditunjukkan bahwa persentase indikator kepuasan mencapai 84\% dan berada pada kategori sangat positif. Hal ini menunjukkan bahwa sebagian besar siswa merasa sangat puas dengan video pembelajaran Youtube yang disajikan. Kepuasan siswa ini mencerminkan bahwa fasilitas pembelajaran yang digunakan oleh guru sudah baik. Hal ini sesuai dengan Hatta (2017) yang mengemukakan bahwa salah satu yang mempengaruhi kepuasan siswa dalam belajar adalah penggunaan fasilitas pembelajaran yang digunakan.

Selain itu, kepuasan belajar memiliki hubungan yang positif terhadap hasil belajar siswa (Dhaqane \& Afrah, 2016; Ko \& Chung, 2014; Putra, 2019). Hasil belajar ini tidak hanya diukur dari nilai tes saja, namun lebih luas mencakup kemampuan pada aspek kognitif, afektif, dan psikomotor. Oleh karena itu, dengan kepuasan belajar yang didapatkan oleh siswa, diharapkan mereka akan mendapatkan hasil belajar yang optimal. 
Pada indikator percaya diri juga memperoleh persentase skor paling sedikit yaitu $79 \%$. Indikator ini terkait dengan kemampuan video dalam memberikan gambaran dalam menyelesaikan tugas mahasiswa, serta keyakinan mahasiswa dalam menyelesaikan tugas setelah mencermati video pada Youtube. Manfaat media youtube dalam proses pembelajaran adalah sebagai media penyampaian materi-materi pembelajaran, sebagai media yang dapat memberikan ilustrasi atas materi pembelajaran, didalamnya terdapat tutorial atau langkah - langkah terhadap materi praktik, tampilan yang menarik sehingga dapat memotivasi siswa dalam mengikuti pembelajaran, dapat menambah wawasan dalam ilmu pengetahuan dan pengalaman belajar, serta dapat membantu dalam proses menyelesaikan masalah pada butir persoalan materi, serta informasi dalam YouTube beranekaragam akan berguna dalam pembelajaran (Sutartu \& Astuti, 2021). Dengan penjelasan manfaat yang ada ketika meresume via Youtube, maka ssiwa diharapkan dapat memiliki gambaran dalam menyelesaikan tugas mereka.

Secara umum, pada aspek tanggapan diperoleh rata-rata $80 \%$ (positif) dimana indikatir format dan relevansi sudah terkategori baik dari segi bahasa dan penyampaian konten. Sedangkan pada aspek reaksi, indikator kepuasan dan percaya diri mendapatkan respon yang positif. Hal ini berarti mahasiswa puas terhadap pengalaman belajar yang diberikan. Senada dengan hasil ini, penelitian sebelumnya tentang media video pembelajaran online mengindikasikan bahwa siswa merasa puas dengan media yang digunakan (Kewalin \& Mike, 2018).

Berdasarkan rata-rata persentase skor untuk setiap indikator, yaitu $80 \%$, diketahui bahwa respon mahasiswa terhadap metode meresume di video Youtube sebagai media pada pembelajaran matematika positif. Dengan demikian, dengan adanya respon positif terhadap media yang digunakan, diharapkan siswa dapat terfasilitasi dan melakukan pembelajaran secara optimal.

Selain aspek positif ketika menerapkan metode meresume di youtube, ada aspek negatif yang disampaikan oleh mahasiswa diantaranya adanya gangguan internet atau internet tidak stabil ketika proses akses youtube berlangsung, boros pemakaian pulsa internet, tidak adanya feedback saat pengaksesan, sehingga materi yang belum dipahami di Youtube, tidak langsung mendapatkan jawaban, kebingungan dalam menentukan akun youtube yang kredibel sehingga ketika ada perbedaan beberapa pendapat tentang materi, akan menyebabkan siswa mengalami kebingungan.

\section{KESIMPULAN}

Hasil rata-rata persentase skor keseluruhan respon mahasiswa terhadap meresume video di Youtube mencapai $80 \%$. Hal ini menunjukkan bahwa respon mahasiswa ketika metika meresume video di Youtube pada pembelajaran matematika adalah positif. Meresume video di Youtube dapat digunakan pada pembelajaran daring khususnya pada pembelajaran matematika yang melibatkan kegiatan prosedural penyelesaian masalah, serta membutuhkan pemahaman pada setiap langkah dan urutan dalam proses penyelesaiannya. Namun begitu, perlu adanya perhatian khusus terkait penyajian 
tampilan video dan teknik/struktur penyampaian materi serta aspek negative yang disampaikan oleh mahasiswa sehingga mahasiswa lebih tertarik dan percaya diri setelah menggunakan media tersebut.

\section{UCAPAN TERIMA KASIH}

Terima kasih kepada suami yang mendukung dalam proses terselesaikannya penelitian ini dan Mahasiswa FKIP PGSD Semester 3 Universitas Muhammadiyah Palangkaraya.

\section{REFERENSI}

Arikunto, S. (2009). Evaluasi Program Pendidikan: Pedoman Teoritis Praktis Bagi Praktisi Pendidikan. Jakarta: Bumi Aksara.

Chandra, F. H., \& Nugroho, Y. W. (2017). Implementasi Flipped Classroom dengan Video Tutorial pada Pembelajaran Fotografi Komersial. Demanda: Jurnal Desain Komunikasi Visual, Manajemen Desain dan Periklanan, 2(1), 20-36. https://doi.org/10.25124/demandia.v2i01.772

Daniati, N. T. (2020). Video Referensi sebagai Solusi Pembelajaran Animasi 3D di Tengah Pandemi Covid-19. Ideguru: Jurnal Karya Ilmiah Guru, 5(1), 64-70. https://doi.org/10.51169/ideguru.v5i1.128

Dhaqane, M. K., \& Afrah, N. A. (2016). Satisfaction of Students and Academic Performance in Benadir University. Journal of Education and Practice, 7(24), 59-63.

Hatta, M. (2017). Unsur-Unsur Dinamis Pembelajaran Fasilitas Belajar dan Motivasi Berprestasi Terhadap Kepuasan Siswa MTs. Manajemen Pendidikan, 12(1), 38-47. https://doi.org/10.23917/jmp.v12i1.2973

Humaidi, H., Qohar, A., \& Rahardjo, S. (2022). Respon Siswa terhadap Penggunaan Video Youtube sebagai Media Pembelajaran Daring Matematika. JIPM (Jurnal Ilmiah Pendidikan Matematika), 10(2), 153-162. https://doi.org/10.25273/jipm.v10i2.9108

Katadata. (2021). Masyarakat Indonesia Paling Banyak Akses YouTube pada Semester I-2021. Diambil 29 Desember 2021, dari https://databoks.katadata.co.id/datapublish/2021/09/05/masyarakat-indonesia-paling-banyakakses youtubepada-semester-i-2021

Kemenkominfo. (2021). Warganet Meningkat, Indonesia Perlu Tingkatkan Nilai Budaya di Internet. Diambil 29 Desember 2021, dari https://aptika.kominfo.go.id/2021/09/warganet-meningkatindonesia-perlu-tingkatkan-nilai-budaya-di-internet/

Kewalin, A., \& Mike, W. (2018). An Experimental Study of Subtitled Online Video Supporting Thai Students Learning English IT Content. Teaching English with Technology, 18(4), 48-70.

Ko, W.-H., \& Chung, F.-M. (2014). Teaching Quality, Learning Satisfaction, and Academic Performance among Hospitality Students in Taiwan. World Journal of Education, 4(5), 11-20. https://doi.org/10.5430/wje.v4n5p11

Lasabuda, N. E. (2017). Pengembangan Media Youtube dalam Pembelajaran Matematika (Suatu 
Penelitian di SMK Kesehatan Bakti Nusantara Gorontalo). Jurnal Riset Dan Pengembangan Ilmu Pengetahuan, 2(2), 270-275.

Lestari, F. M., \& Bahrozi, I. (2021). Pemanfaatan Media Sosial Berbasis Youtube Dalam Pembelajaran Tematik Kelas 2 di Masa Pandemi Covid-19. PEDIR: Journal of Elementary Education, 1(1), 11-22.

Lijana, L., Panjaitan, R. G. P., \& Wahyuni, E. S. (2020). Respon siswa Terhadap Media Pembelajaran Komik pada Materi Ekologi di kelas X SMA. Jurnal Pendidikan dan Pembelajaran Khatulistiwa, 3(7).

Molina, C. (2014). Teaching Mathematics Conceptually. SEDL insights, 1(4), 1-8.

Mujianto, H. (2019). Pemanfaatan Youtube Sebagai Media Ajar dalam Meningkatkan Minat dan Motivasi Belajar. Jurnal Komunikasi Universitas Garut: Hasil Pemikiran dan Penelitian, 5(1), 135-159. https://doi.org/http://dx.doi.org/10.10358/jk.v5i1.588.g566

Pambudi, R., Afghohani, A., \& Farahsanti, I. (2019). Pengaruh Media Video Youtube Terhadap Prestasi Belajar Matematika Pada Siswa Kelas X SMK Negeri 2 Sukoharjo Tahun Ajaran 2017/2018. Jurnal Pendidikan, 28(2), 175-182. https://doi.org/https://doi.org/10.32585/jp.v28i2.345

Putra, I. D. G. R. D. (2019). Peran Kepuasan Belajar Dalam Mengukur Mutu Pembelajaran Dan Hasil Belajar. Jurnal Penjaminan Mutu, 5(1), 22-31. https://doi.org/10.25078/jpm.v5i1.756

Riduwan. (2007). Skala Pengukuran Variabel-variabel Penelitian. Bandung: Alfabeta.

Sadikin, A., \& Hamidah, A. (2020). Pembelajaran Daring di Tengah Wabah Covid-19. BIODIK, 6(2), 214-224. https://doi.org/10.22437/bio.v6i2.9759

Sari, L. (2020). Uapaya Menaikkan Kualitas Pendidikan dengan Pemanfaatan Youtube sebagai Media Ajar pada Masa Pandemi Covid-19. Jurnal Tawadhu, 4(1), 1074-1084.

Setiyana, F. N., \& Kusuma, A. B. (2021). Potensi Pemanfaatan Youtube dalam Pembelajaran Matematika. EduMatSains: Jurnal Pendidikan, Matematika dan Sains, 6(1), 71-90. https://doi.org/https://doi.org/10.33541/edumatsains.v6i1.2945

Siyoto, S., \& Sodik, A. (2015). Dasar Metodologi Penelitian. Yogyakarta: Literasi Media Publishing. Srinivasacharlu, A. (2020). Using YouTube in Colleges of Education. Shanlax International Journal of Education, 8(2), 21-24.

Sutartu, T., \& Astuti, W. (2021). Dampak Media Youtube dalam Proses Pembelajaran dan Pengembangan Kreatifitas Bagi Kaum Milenial. Widya Aksara: Jurnal Agama Hindu, 26(1), 89101.

Suwarno, M. (2017). Potensi Youtube Sebagai Sumber Belajar Matematika. Pi: Mathematics Education Journal, 1(1), 1-7. https://doi.org/10.21067/pmej.v1i1.1989

Tarida, L., \& Indriyani. (2020). Pemanfaatan Google Classroom dan Video Pembelajaran berbasis Problem Solving sebagai Solusi Kegiatan Belajar Mengajar di Era Pandemi Covid-19. Saintara: Jurnal Ilmiah Ilmu-Ilmu Maritim, 5(1), 16-20. 
Tutiasri, R. P., \& Laminto, N. K. (2020). Pemanfaatan Youtube Sebagai Media Pembelajaran Bagi Mahasiswa di Tengah Pandemi Covid-19. Jurnal Komunikasi Masyrakat dan Keamanan, 2(2).

Whitehead, A. N. (2012). An Introduction To Mathematics. London: Williams \& Norgate.

Wirasasmita, R. H., \& Putra, Y. K. (2018). Pengembangan Media Pembelajaran Video Tutorial Interaktif menggunakan Aplikasi Camtasia Studio dan Macromedia Flash. EDUMATIC: Jurnal Pendidikan Informatika, 1(2), 35. https://doi.org/10.29408/edumatic.v1i2.944

Ziegler, G. M., \& Loos, A. (2010). Teaching and Learning: What is Mathematics. Berlin: Freie Universitat Berlin. 